\title{
Bottom Sediment Characteristics of a Tropical Lake: Lake Tana, Ethiopia
}

\author{
Mebrahtom G. Kebedew ${ }^{1,2}$, Seifu A. Tilahun ${ }^{1}$, Fasikaw A. Zimale ${ }^{1}{ }^{1}$ and \\ Tammo S. Steenhuis $1,3, * \mathbb{D}$ \\ 1 School of Civil and Water Resources Engineering, Bahir Dar University, Bahir Dar 1000, Ethiopia; \\ mebrehydro@gmail.com (M.G.K.); satadm86@gmail.com (S.A.T.); fasikaw@gmail.com (F.A.Z.) \\ 2 School of Civil Engineering, Mekelle University, Mekelle 1000, Ethiopia \\ 3 Department of Biological and Environmental Engineering, Cornell University, Ithaca, NY 14850, USA \\ * Correspondence: tss1@cornell.edu; Tel.: +1-607-255-2489
}

Received: 20 February 2020; Accepted: 16 March 2020; Published: 19 March 2020

\begin{abstract}
Sediment concentration of rivers in developing countries has been increasing greatly over the last 50 years due to the conversion of forest to continuously cultivated land with the increasing population. Few studies have addressed its effect on sedimentation and water quality of the lakes by analyzing bottom sediment characteristics. In this study, the objective was to investigate the spatial distribution (and their interrelationships) of the bottom sediment characteristics in the largest lake in Ethiopia, Lake Tana where water hyacinths have been spreading rapidly during the last decade. Sediment samples were collected from the lake bottom at 60 locations and analyzed for texture, organic matter, total nitrogen, and available phosphorus. Bottom sediment samples had a median of $75 \%$ clay, $13 \%$ silt, and $9 \%$ sand. Clay was greatest in the northwestern part and smallest in the areas near the major rivers entering or exiting the lake. Clay percentage and lake depth were strongly correlated. The mean organic matter content of bottom sediment was $16 \mathrm{~g} \mathrm{~kg}^{-1}$, total nitrogen $0.8 \mathrm{~g}$ $\mathrm{kg}^{-1}$, and Olsen available phosphorus $19 \mathrm{mg} \mathrm{kg}^{-1}$. Phosphorus concentrations peaked where water hyacinths were found in the northeastern part of the lake. This study will serve as a baseline for future water quality and sedimentation changes in Lake Tana. In particular, it might aid in explaining the spread of the water hyacinths.
\end{abstract}

Keywords: tropical lake; sedimentation; deposition; soil texture; Nile basin; organic matter; total nitrogen; available phosphorus

\section{Introduction}

Lakes are vital in preserving regional environmental and ecological functions and services, such as potable water, irrigation, power generation, fishery, flood contrail, and drought buffer [1]. These functions have been declining especially in the developing world due to rapid population growth that has accelerated land degradation, increasing the amount of sediment and nutrient transported by rivers [2]. Most of the sediment is deposited in floodplains, lakes, and reservoirs [3]. Deposited materials consist of inorganic and organic materials with adsorbed nutrients and contaminants and can threaten the sustainability of lakes [4,5]. The characteristics of suspended and lake bottom sediment composition and associated nutrients depend on the characteristics of the surrounding watershed $[6,7]$, prevailing climate $[4,8]$, and on the residence time [8-11].

Research on the spatial distribution of bottom sediment characteristics aids in lake management strategies. To do so, previous studies have determined: the spatial distribution pattern to understand sedimentation conditions in Lake Abaya and Chamo, Ethiopia [12] and Kodaikanal and Akkulam-Veli Lake, India [9,10,13]; the source of the organic matter deposition in Lake Victoria [14], Lake Kodaikanal, 
Manasbal, Wular, and Anchar lakes, India [15,16]; distribution of total phosphorus in Southern Green Bay of Lake Michigan [17], the release of nutrients from the bottom sediments in the water column for Lake Rotoiti in New Zealand [18] and Poyang Lake in China [19]; and the overall implication on lake sustainability of Minnesota lakes, USA [20].

In this study, the current lake bottom sediment characteristics of Lake Tana were investigated. The total sediment layer in Lake Tana accumulated over a 250,000 year period is greater than $100 \mathrm{~m}$ [21,22]. Less than 100 years ago, Lake Tana was described as a pristine lake with a sandy bottom at the inlets [23]. In the 1960s, with the increasing population pressure, sedimentation of the lake increased greatly over historic rates and river deltas formed [24]. The water quality of the lake declined as well [25] with the increased sediment-associated and dissolved nutrient inputs [26]. This has resulted in poor light penetration [27], declined fish production [28], and increased water hyacinth acreage from 20 ha in 2012 to over 30,000 ha or 10\% of the lake area in 2018 [29].

Most of the previous research on Lake Tana focused on pollution [30], eutrophication [31], water hyacinth coverage and potential infestations [29,32], the effect of nutrient availability and water transparency on primary production [25], location dynamics of the major phytoplankton and zooplankton communities [33], ecohydrological status, fisheries and fish evaluation biology [34] sediment physicochemical characteristics [35], and the status of water quality [36]. Several bathymetries surveys were conducted indicating sedimentation rates of $12 \mathrm{Tg} \mathrm{yr}^{-1}$ to $108 \mathrm{Tg} \mathrm{yr}^{-1}$ [37]. Finally, sediment budget calculations showed that a major portion of the sediment was deposited in the river floodplains $[38,39]$.

Despite these studies, little is known about the lake bottom sediment characteristics and nutrient content. The only recent study available [35] reports on the nutrient sediment content of 20 samples taken near the lakeshore with aquatic vegetation. Studies on sediment characteristics are not available. The objective is therefore, to investigate the spatial distribution (and their inter relationships) of the bottom sediment characteristics throughout Lake Tana. The texture and the organic matter, total nitrogen and available phosphorus content of the bottom sediments, and the lake depth were measured in approximately a $10 \mathrm{~km}$ by $10 \mathrm{~km}$ grid with additional measurements taken close to the shoreline.

\section{Materials and Methods}

\subsection{Study Area}

Lake Tana, located in the headwaters of the Blue Nile in the north-western Ethiopian highlands, is the largest lake in Ethiopia (Figure 1) [27]. The average depth is $9 \mathrm{~m}$, and the area is $3041 \mathrm{~km}^{2}$ [40]. It serves as a natural reservoir for Tis Abay and Tana Beles hydropower stations. It is an important source of income for the local communities [41]. The lake water is used for irrigation, hydropower, fishing, transportation, and tourism [42]. Lake Tana and surrounding areas were designated by the government as a growth corridor with several irrigation schemes [43].

The lake is fed by more than 40 seasonal rivers and 4 permanent rivers: Gilgel Abay from the south, Megech from the north, and Gumara and Rib from the east. The major rivers contribute about $80 \%$ of the total annual inflow and $62 \%$ of the sediment load to the lake $[39,44]$. The sediment concentrations in the rivers have been increasing in the past fifty years [24]. Sediment concentrations of more than $10 \mathrm{~g} \mathrm{~L}^{-1}$ are not uncommon from watersheds with active gully erosion [45]. In addition, the nutrient input from the upland agricultural areas has increased $[26,46]$. Phosphorus concentrations in the lake water have been rising [47] and have resulted in a progressive change of the lake from mesotrophic to eutrophic status [31].

\subsection{Bottom Sediment Sampling}

From 27 February to 6 March 2018, sediment samples were collected from deposited sediments at the bottom of Lake Tana. In the main part of the lake at a depth greater than $10 \mathrm{~m}$ depth where the sedimentation was uniform, samples were taken in a grid of approximately $10 \mathrm{~km}$ by $10 \mathrm{~km}$ (Figure 1 
shows the $10 \mathrm{~m}$ contour line). At depths less than $10 \mathrm{~m}$ in the nearshore areas, additional bottom sediment samples were taken at locations where sediment composition was expected to change rapidly (Figure 1). A total of 60 sediment samples were collected The GPS locations of all sampling locations were used for navigation. The standard Ekman grab sampler [48] was used to collect bottom sediment samplers. For sampling at a depth greater than $6 \mathrm{~m}$, a weight of $8 \mathrm{~kg}$ was attached to the sampler (Figure 2 shows the configuration). The minimum weight of the sediment sample collected was $1 \mathrm{~kg}$, which was a wet weight. In cases where a greater sample was collected; a subsample was taken from 1 to $1.5 \mathrm{~kg}$. After collection, samples were labeled and stored in a sealed bag for further analysis (Table A1 in the Appendix A).

(a)
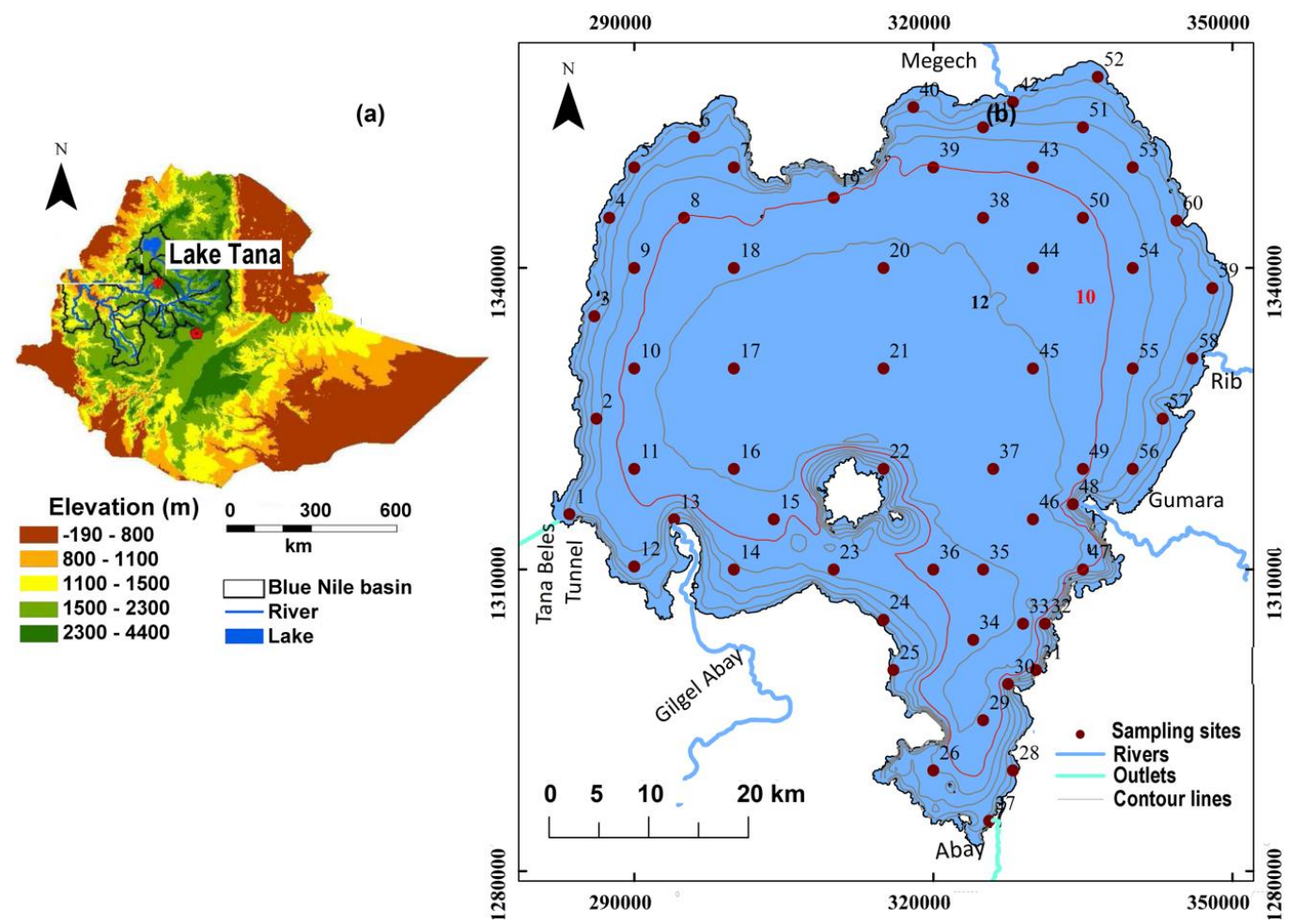

Figure 1. Location map of the study area (a). The map of Ethiopia and Ethiopian lakes superimposed on the national geography world map (b). Bottom sediment sampling sites on Lake Tana and major inflow-outflow rivers. The contour lines indicate the depth of the lake at $2 \mathrm{~m}$ intervals. The red contour is the $10 \mathrm{~m}$ depth contour.

\subsection{Analytical Methods}

Collected bottom sediment samples were analyzed in Amhara Design and Supervision Works Enterprise, Soil Chemistry Laboratory. Sediment samples were air-dried, ground, and passed through a $2 \mathrm{~mm}$ sieve. The hydrometer method was used for determining the sand, silt, and clay fractions [49]. The textural classification was based on USDA soil classification criteria [50]. Organic matter content was determined with the Walkley Black rapid titration method, total nitrogen with Kjeldahl's method, and available phosphorus with the Olsen method [51]. The organic carbon content was derived assuming that $58 \%$ of organic matter is organic carbon [52].

\subsection{Interpolation}

The analytical data for the 60 bottom sediment sampling points were entered in Excel and then imported into Geospatial Analyst Tool extension, ArcGIS (version 10.4.1), for interpolation. The ordinary kriging, geostatistical interpolation, with an exponential semi-variogram method was used to find the spatial distribution of bottom sediment texture, organic matter, total nitrogen, $\mathrm{C} / \mathrm{N}$, and available 
phosphorus of the lake. Unlike the deterministic method, ordinary kriging uses autocorrelation or statistical relationships among a group of measured points to create surfaces [53]. A best fit exponential semi-variogram is fitted to the empirical semi-variogram that depicts the spatial autocorrelation of the measured points. The fitted semi-variogram will further be used to predict the unknown points within the measured values for spatial interpolation.

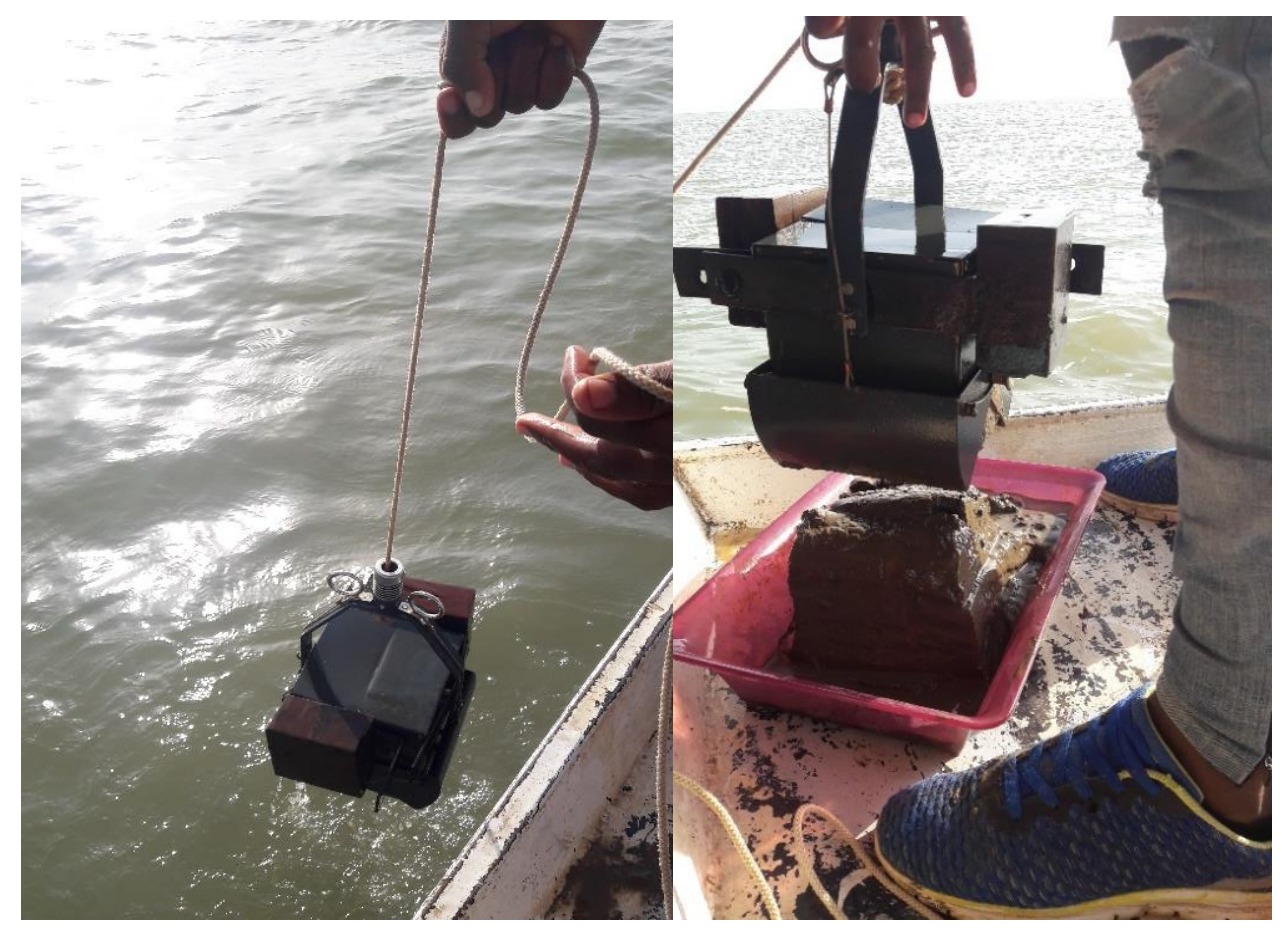

Figure 2. Bottom sediment sample collection from Lake Tana (photo taken on 3 March, 2018).

\subsection{Statistical Methods}

Microsoft Excel 2019 was used to calculate the descriptive statistics, box plots, and to perform regression analysis with lake depth on the bottom sediments. The relationship between measured sediment parameters was evaluated with Pearson's correlation matrix.

\section{Results}

\subsection{Bottom Sediment Characteristics of Lake Tana}

The bottom sediment had an average of $16 \%$ sand, $17 \%$ silt, and $67 \%$ clay. The median is $13 \%$ sand, $9 \%$ silt, and $75 \%$ for clay (Table A1 in the Appendix A). The clay content was positively skewed with lower outliers, and sand and silt fractions were negatively skewed with upper outliers (Figure 3 , Table S1 in the Supplemental Material). Based on USDA soil classification, the bottom sediment composition, texture class, was mainly clay with limited occurrence of sandy loams at sampling points 13,27 , and 31 , silty loams at sampling points 1 (Tana Beles tunnel inlet) and 25, silty clay loam at sampling points 58,24 , and 28, and silty clay at sampling points 56 and 57 (Figure 4; locations of the sampling points are given in Figure 1).

The average organic matter content of the sediment was $16 \mathrm{~g} \mathrm{~kg}^{-1}$ with a range of 7 to $24 \mathrm{~g} \mathrm{~kg}^{-1}$, total nitrogen was from 0.3 to $1.2 \mathrm{~g} \mathrm{~kg}^{-1}$ with an average value of $0.8 \mathrm{~g} \mathrm{~kg}^{-1}$, and the sediment available phosphorus was $19 \mathrm{mg} \mathrm{kg}^{-1}$ and ranged between 3.5 to $39 \mathrm{mg} \mathrm{kg}^{-1}$ (Table A1). The organic matter was with lower outliers, total nitrogen was normally distributed, and available phosphorus and the $\mathrm{C} / \mathrm{N}$ ratio were positively skewed (Table S1 in the Supplemental Material). However, the medians are fairly close to the center of the box, and the whiskers are of approximately equal length for the contents of organic matter, total nitrogen, $\mathrm{C} / \mathrm{N}$, and available phosphorus (Figure 3). 

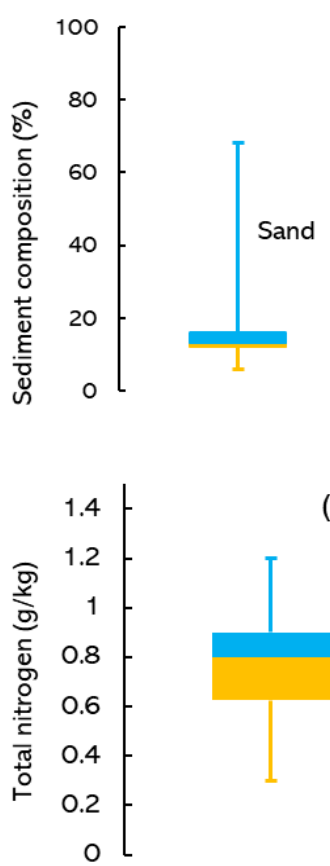

(a)

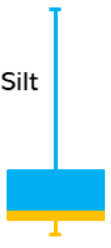

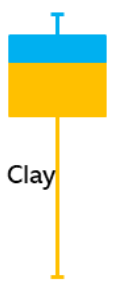
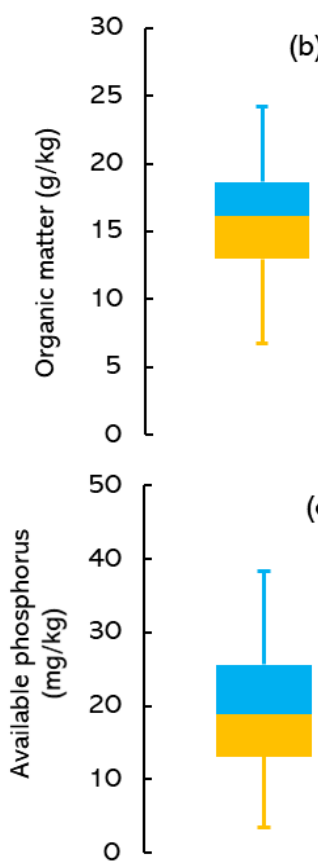

(b)

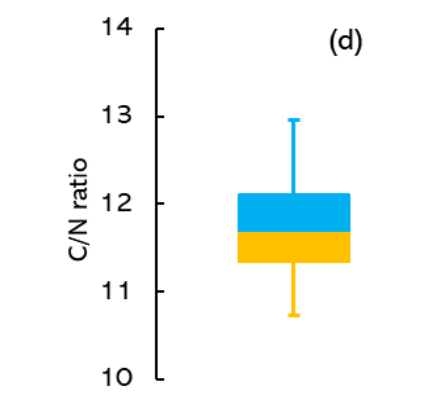

(d)

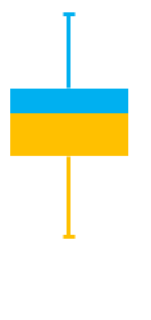

(c) (b)

(e)

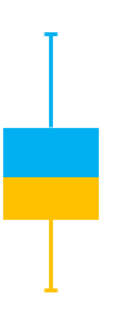

Figure 3. Box plots for bottom sediment characteristics of Lake Tana; (a) texture, (b) organic matter content, (c) total nitrogen, (d) C/N, and (e) available phosphorus.

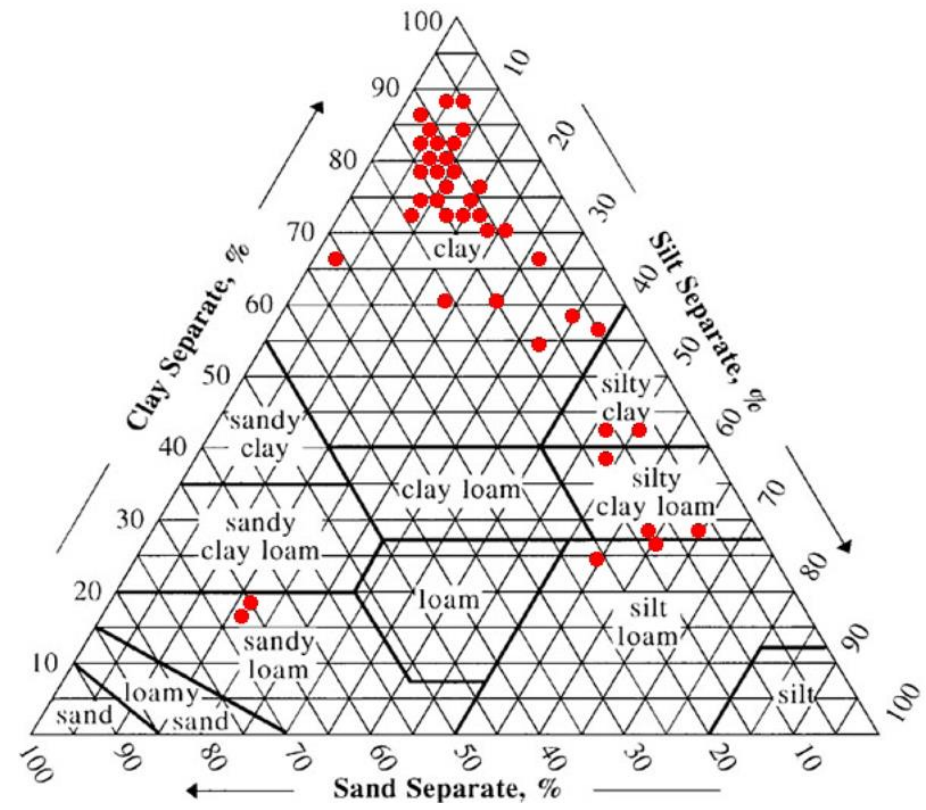

Figure 4. Bottom sediment texture triangle of Lake Tana based on USDA soil classification criteria.

\subsection{Spatial Distribution}

Based on the 60 bottom sediment samples, maps were created using ordinary kriging with an exponential semi-variogram (Figure S1 in the Supplemental Material) of the contents of sand, silt, and clay (Figure $5 \mathrm{a}-\mathrm{c}$ ), the concentrations of organic matter, total $\mathrm{N}$ and available $\mathrm{P}$ (Figure $5 \mathrm{~d}-\mathrm{f}$ ), and the $\mathrm{C} / \mathrm{N}$ ratio, which has the lowest RMSE value. The sediment composition data (Figure 3) had a large skew and were log-transformed to make the distribution normal. The other parameters were normally distributed. 

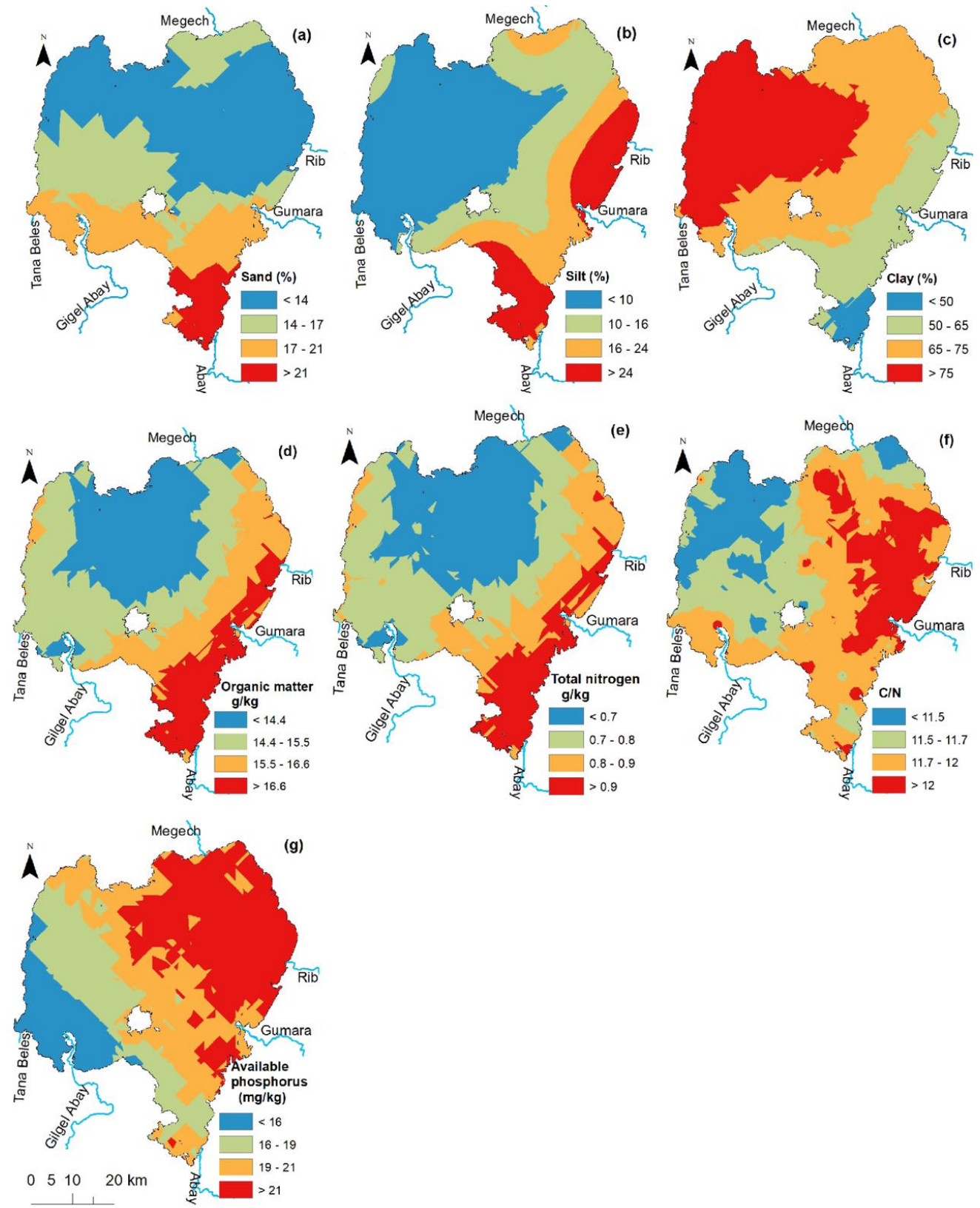

Figure 5. Bottom sediment characteristics of Lake Tana: Sediment composition; (a) sand, (b) silt, (c) clay percentages, (d) organic matter concentration of sediment, (e) total nitrogen concentration of sediment, (f) carbon to nitrogen ratio, and (g) available phosphorus concentration of the sediment.

The semi-variograms depicted in Figure S1 show there was a large nugget effect for all measured parameters indicating that the variation at a distance smaller than approximately $10 \mathrm{~km}$ was large compared to the sill or the maximum variability between two points. In the case of the organic matter, total N, and available phosphorus (Figure S1d-f), the nugget effect and the sill are almost equal, indicating that the large- and small-scale variability are nearly equal. The clay percentage (Figure S1c) is the only parameter that shows a good spatial dependence with an effective range (defined as lag at which $95 \%$ of the sill is exceeded) of $50-60 \mathrm{~km}$.

The kriged maps in Figure 5 show that the sand and silt fractions were the greatest near the outlet of the lake (Figure $5 a, b$ ) where the Blue Nile starts. One sampling point (13) near the Gilgel Abay had the greatest sand content (68\%, Table A1). Silt content was also elevated near Rib and Gumara rivers on the east side of the lake (station 48) and Rib inlet (station 58). The largest amount of clay content 
was found at the northwestern and deeper parts of the lake (Figure 5c). More than $42 \%$ of the lakebed had more than $75 \%$ clay, and only $3 \%$ of the lake had less than $50 \%$ clay.

The spatial distribution of the organic matter, (including organic carbon), and total nitrogen in the bottom sediments was similar. The minimum concentrations were observed in the central and the northern parts and the maximum in the southern and eastern sides of the lake (Figure $5 \mathrm{~d}-\mathrm{f}$ ). Organic matter content greater than $20 \mathrm{~g} \mathrm{~kg}^{-1}$ was observed at sampling points 41 near Megech inlet, 58, 47, $44,59,60$, and 57 near Rib inlet and nearby areas, and 28 and 32 in the southeastern part (Figure $5 \mathrm{~d}$; Table A1; Figure 1 gives the locations of the sampling stations). The largest $\mathrm{C} / \mathrm{N}$ ratios were observed in the southeastern part of the lake near the Gumara and Rib rivers. The southwestern part had relatively more carbon than nitrogen (Figure 5e). Available phosphorus increased from the western part near the Gilgel Abay River inlet to the northeast in an area that stretches for Megech and Rib rivers (Figure 5g). The latter was the location where the water hyacinths are most prominent.

\subsection{Correlation}

The analysis showed a very strong positive correlation between the contents of organic matter and total nitrogen and a strong correlation between clay content and lake depth. A weak correlation between silt content and organic matter and silt content and total nitrogen was found. A strong negative correlation occurred between silt and clay content and between silt content and lake depth. A moderate negative correlation was observed between sand and clay content. However, the linear correlation of available phosphorus with the other parameters was very weak. In addition, the linear correlation sand fraction with all measured parameters except clay content was very weak.

\subsection{Relationship with Lake Depth}

The results of regression plots (Figure 6a,b) confirm the results in Table 1 that with increasing lake depth, the clay content increased, and the silt content decreased. All other measured parameters were not related to lake depth, although in some cases a weak trend could be detected (Figure S2 in the Supplemental Material).
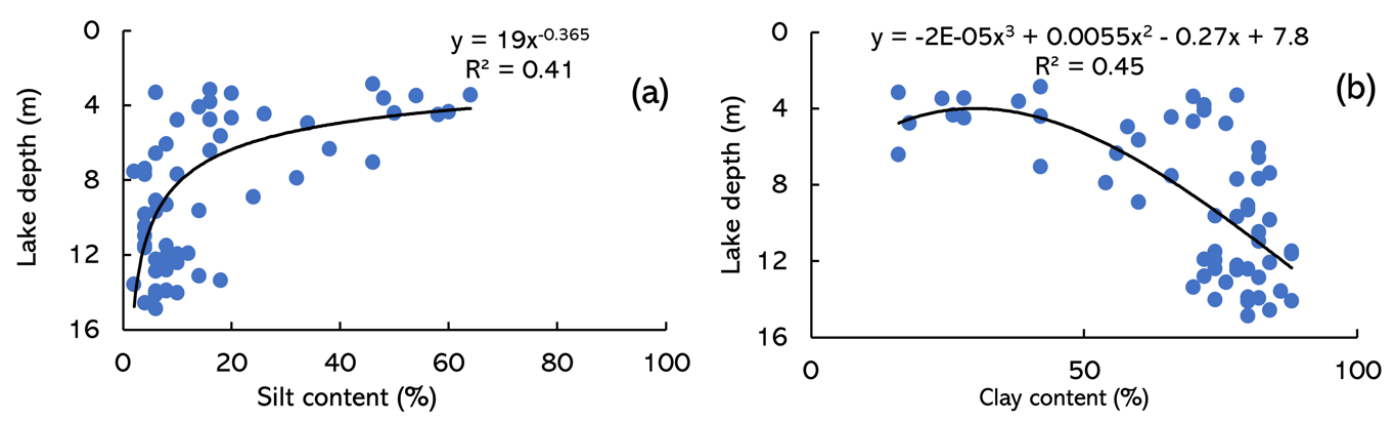

Figure 6. Bottom sediment texture of Lake Tana: (a) silt content with lake depth and (b) clay content with lake depth.

Table 1. Pearson correlation coefficient for bottom sediment properties of Lake Tana. OM is organic matter; TN is total N. and Av.P is available phosphorous

\begin{tabular}{lrrrrrrr}
\hline & Sand (\%) & Clay (\%) & Silt (\%) & OM (g/kg) & TN (g/kg) & C/N Ratio & Av.P (mg/kg) \\
\hline Sand (\%) & 1 & & & & & & \\
Clay (\%) & -0.581 & 1 & & & & & \\
Silt (\%) & -0.049 & -0.784 & 1 & & & & \\
OM (g/kg) & -0.051 & -0.244 & 0.338 & 1 & & & \\
TN (g/kg) & -0.071 & -0.206 & 0.307 & 0.993 & 1 & & \\
C/N & 0.175 & -0.265 & 0.192 & -0.199 & -0.307 & 1 & \\
Av.P (mg/kg) & -0.137 & 0.026 & 0.072 & 0.013 & 0.036 & -0.146 & \\
Depth (m) & -0.192 & 0.621 & -0.615 & -0.237 & -0.223 & -0.048 & 0.140 \\
\hline
\end{tabular}




\section{Discussion}

The bottom sediments of Lake Tana were sampled on a grid of approximately 10 by $10 \mathrm{~km}$ (Figure 1). The 60 -sediment sample had a median of $75 \%$ clay, $9 \%$ silt, and $13 \%$ sand (Figure 3; Table A1). Averages due to the skewness of the textural composition (Figure 3) are lower flow clay with $65 \%$ and slightly greater for both silt (17\%) and sand (16\%). The sediments in the deepest part of the lake had the greatest percentage clay and were classified according to the USDA classification as clay (Figure 4). Sandy deposits were found near the inlet of the major rivers and outlet to the Blue Nile (Figure 5). The sand concentration near the major rivers is greater, especially near the Gilgel Abay, which does not have a substantial floodplain, because sand drops out first due to its fast settling velocity [54]. The rapid growth of the peninsulas of Gilgel Abay [40] and Gumara [55] are also a result of this process. The high sand content near the exit of the Blue Nile is caused by a different process and originates from the sediments resuspended by the wind; the suspended fine particles are transported away in the Blue Nile river water, leaving the sand particles behind [56].

In comparing the bottom sediments of Lake Tana, we find that the bottom sediment samples from the northern part of the $223,000 \mathrm{~km}^{2}$ Lake Victoria (Uganda and Kenya) have a slightly lower clay percentage of $61 \%$, more silt $35 \%$, and less sand (4\%) [57]. The textural classification of the 947 samples from Lake Abaya and Chamo in the southern part of Ethiopia is mainly silty clay, indicating less clay and more silt than Lake Tana. The depth of these two lakes is approximately the same, but the surface area is only one-third of Lake Tana [12]. The small tropical Lake Berijam in India of $0.24 \mathrm{~km}^{2}$ consists of silty and sandy clays [15].

The bottom sediments of, the on average over $300 \mathrm{~m}$ deep and 33,000 $\mathrm{km}^{2}$ large, Lake Tanganyika and the $270 \mathrm{~m}$ deep and $30,000 \mathrm{~km}^{2}$ Lake Malawi in the Rift Valley are much sandier than Lake Tana [58-60]. The sediments near the inlets of the rivers have more clay than the rest of Lake Malawi due to the deposition of eroded material from agricultural fields [58,60]. Another tropical lake with a sandier bottom than Lake Tana is the $9 \mathrm{~m}$ deep and $160 \mathrm{~km}^{2}$ large Lake Navashi in Kenya that has $33 \%$ clay, $40 \%$ silt, and 30\% sand [61]. The inflow and outflow to this lake that is located in the Rift valley was mostly via the subsurface. Finally, the bottom sediment of the small tropical Kadaikanal Lake India was sand.

The organic matter content in this study with an average of $16 \mathrm{~g} \mathrm{~kg}^{-1}$ (Figure 3b, Table A1) was greater than that of the limited data collected 20 years ago [62] but less than the study conducted 5 years ago that sampled the lake near the shoreline [35] that was dominated by aquatic plants [36]. The organic matter content on Lake Tana was small compared with Lake Abaya and Chamo [12] in Ethiopia, Lake Victoria [14] in Central Africa, and the Waler and Berijam lakes in India [19,63]. The low organic matter and total $\mathrm{N}$ content in Lake Tana is a consequence of agricultural land in the watershed that is low in organic matter and the shallow depth. Because of the shallow depth, the lake is well-mixed and fully oxidized, enhancing mineralization [16]. The lowest percentage of organic matter in the western and deeper areas indicates that the mineralization in the deepest part of the lake is enhanced [64]. The southern part is also influenced by the urbanized areas and aquatic plants.

The $\mathrm{C} / \mathrm{N}$ ratio varied from 10.5 to 13 and was greater on the east side of the lake than the west site (Figures 3 and 5). The source of organic matter in the sediment of Lake Tana was from both aquatic and terrestrial origins because algae have a $C / N$ ratio of less than 10 and terrestrial inputs have a $C / N$ ratio greater than 20 [65]. In the deeper parts on the west side of the lake farthest away from the main rivers with the $\mathrm{C} / \mathrm{N}$ ratios closest to 10 , there is mainly aquatic organic matter, while in the western part, some terrestrial organic matter is mixed in.

The available phosphorus in the sediment ranged from $4 \mathrm{mg}$ to $31 \mathrm{mg} \mathrm{kg}^{-1}$. The greatest concentrations were found in the northeast part of the lake. This was also the location where the water hyacinths were found [29,32]. The available phosphorus concentrations in the lake bottom sediments were not related to any other measured parameter (Table 1), indicating that the conversion processes that caused the pattern are unique. We should note that Gumara and Rib rivers that enter the lake on the east side have during the rainy season a dissolved P concentration that exceeds the 
lake concentration $[27,30,47,66]$. In the Awramba watershed close to lake outlet, the concentration was about three to four times the observed average dissolved phosphorus content in the lake of $0.18 \mathrm{mg} \mathrm{L}^{-1}[26,66]$. This excess dissolved $\mathrm{P}$ concentration will adsorb on the lake sediment until a new equilibrium is established, thereby increasing the sediment phosphorus concentration. However, it is not obvious why this increase in bottom concentration is the greatest in the northeast side of the lake. A planned study on lake circulation might provide the answer.

\section{Conclusions}

Sixty sediment samples were collected from the bottom of Lake Tana. Textural analysis of the samples showed that the sediment was mainly clay. Spatially, silt and sand fractions were mixed in with the clay near the inlet of the four major rivers and Blue Nile outlet. Clay content was strongly related with lake depth and silt content was negatively correlated. The average organic matter content of the bottom sediment was $16 \mathrm{~g} \mathrm{~kg}^{-1}$, total nitrogen $0.8 \mathrm{~g} \mathrm{~kg}^{-1}$, and available phosphorous $19 \mathrm{mg} \mathrm{kg}^{-1}$ and were not correlated significantly with lake depth. Available phosphorus that was not correlated with any of the measured parameters was the greatest in the shallow northeastern part of the lake that was invaded by water hyacinths. Future studies will address the spatial distribution the bottom sediment with suspended sediment and dissolved nutrients in the river and lake water circulation including water hyacinth invasion.

Supplementary Materials: The following are available online at http://www.mdpi.com/2306-5338/7/1/18/s1, Table S1, Descriptive statistics of Lake Tana bottom sediment composition and sediment nutrients: organic matter, organic carbon, total nitrogen, $\mathrm{C} / \mathrm{N}$ ratio, and available phosphorus fractions. Figure S1, Kriging variogram model for spatial distribution of Lake Tana bottom sediment characteristics: (a) sand fraction, (b) silt fraction, (c) clay fraction, (d) organic matter fraction, (e) sediment total nitrogen, (f) sediment available phosphorus, and (g) carbon to nitrogen ratio on Lake Tana bottom sediments. Figure S1, bottom sediment characteristics of Lake Tana: (a) sand content with lake depth, (b) organic matter content with lake depth, (c) sediment total nitrogen content with lake depth, (d) C/N ratio with lake depth, and (e) sediment available phosphorous content with lake depth.

Author Contributions: M.G.K. contributed during conceptualization, data collection, data analysis, writing the original draft manuscript, and improving the manuscript based on the comments and suggestions of the coauthors. S.A.T. contributed in shaping the objective, methods, project administration, supervision, review, and editing. F.A.Z. helped in conceptualizing the study and providing comments and suggestions. T.S.S. contributed during conceptualization, overall content, structure and English of the paper, improving the English, and supervising. All authors have read and agreed to the published version of the manuscript.

Funding: The research was funded by the EXCEED-SWINDON project "Excellence Center for Development Cooperation-Sustainable Water Management in developing countries" centered at Technical University of Braunschweig, Germany and Blue Nile Water Institute of Bahir Dar University Ethiopia. Additional funding was provided by the Robert S. McNamara Fellowships Program (World Bank), and an anonymous gift made to Cornell.

Acknowledgments: We acknowledge the dedication of Bantesew Muluye and Getahun Birara during sampling of the bottom sediment of Lake Tana. They also shared willingly in the dangers of sampling of the $3000 \mathrm{~km}^{2} \mathrm{Lake}$ Tana in a small boat.

Conflicts of Interest: The authors declare that they do not have a conflict of interest. 


\section{Appendix A}

Table A1. Bottom sediment characteristics (texture, organic matter (OM), total nitrogen (TN), available phosphorus (AV.P), organic carbon (OC), C/N ratio, lake depth (Dept.), and texture class).

\begin{tabular}{|c|c|c|c|c|c|c|c|c|c|c|c|c|}
\hline $\begin{array}{l}\text { Sit. } \\
\text { No }\end{array}$ & $x$ & $\mathbf{Y}$ & $\begin{array}{c}\text { Sand } \\
(\%)\end{array}$ & $\begin{array}{l}\text { Clay } \\
(\%)\end{array}$ & $\begin{array}{l}\text { Silt } \\
(\%)\end{array}$ & $\underset{\mathrm{kg}^{-1}}{\mathrm{OMg}}$ & $\begin{array}{l}\text { TN g } \\
\mathrm{kg}^{-1}\end{array}$ & $\begin{array}{l}\text { OC g } \\
\mathrm{kg}^{-1}\end{array}$ & $\mathrm{C} / \mathrm{N}$ & $\begin{array}{c}\text { Av. P mg } \\
\text { kg }^{-1}\end{array}$ & $\begin{array}{l}\text { Dept. } \\
\text { (m) }\end{array}$ & Texture Class \\
\hline 1 & 283000 & 1315000 & 10 & 82 & 8 & 12.1 & 0.6 & 7 & 11.7 & 9.5 & 6.1 & Silty loam \\
\hline 2 & 286200 & 1325000 & 12 & 78 & 10 & 13.4 & 0.7 & 7.8 & 11.1 & 15.4 & 7.7 & Heavy clay \\
\hline 3 & 286000 & 1335200 & 14 & 76 & 10 & 18.2 & 0.9 & 10.6 & 11.7 & 8.6 & 4.8 & Heavy clay \\
\hline 4 & 287500 & 1345000 & 10 & 70 & 20 & 19.5 & 1.0 & 11.3 & 11.3 & 12 & 4.7 & Heavy clay \\
\hline 5 & 290000 & 1350000 & 10 & 70 & 20 & 14.8 & 0.7 & 8.6 & 12.3 & 12 & 3.4 & Heavy clay \\
\hline 6 & 296000 & 1353000 & 16 & 78 & 6 & 17.5 & 0.9 & 10.2 & 11.3 & 6.9 & 3.3 & Heavy clay \\
\hline 7 & 300000 & 1350000 & 14 & 82 & 4 & 11.4 & 0.6 & 6.6 & 11 & 17.1 & 7.7 & Heavy clay \\
\hline 8 & 295000 & 1345000 & 14 & 82 & 4 & 16.1 & 0.8 & 9.3 & 11.7 & 22.3 & 10.5 & Heavy clay \\
\hline 9 & 290000 & 1340000 & 16 & 78 & 6 & 17.5 & 0.9 & 10.2 & 11.3 & 27.4 & 9.7 & Heavy clay \\
\hline 10 & 290000 & 1330000 & 8 & 88 & 4 & 14.1 & 0.7 & 8.2 & 11.7 & 10.3 & 11.6 & Heavy clay \\
\hline 11 & 290000 & 1320000 & 8 & 88 & 4 & 16.1 & 0.8 & 9.3 & 11.7 & 7.8 & 11.5 & Heavy clay \\
\hline 12 & 290000 & 1310300 & 12 & 82 & 6 & 16.1 & 0.8 & 9.3 & 11.7 & 21.4 & 6.6 & Heavy clay \\
\hline 13 & 294000 & 1315000 & 68 & 16 & 16 & 10.8 & 0.5 & 6.3 & 12.5 & 8.6 & 3.2 & Sandy loam \\
\hline 14 & 300000 & 1310000 & 14 & 80 & 6 & 20.2 & 1.0 & 11.7 & 11.7 & 7.8 & 9.1 & Heavy clay \\
\hline 15 & 304000 & 1315000 & 16 & 78 & 6 & 9.4 & 0.5 & 5.5 & 10.9 & 14.6 & 12.2 & Heavy clay \\
\hline 16 & 300000 & 1320000 & 12 & 86 & 2 & 16.1 & 0.8 & 9.3 & 11.7 & 8.6 & 13.6 & Heavy clay \\
\hline 17 & 300000 & 1330000 & 6 & 88 & 6 & 13.4 & 0.7 & 7.8 & 11.1 & 18.9 & 14.1 & Heavy clay \\
\hline 18 & 335000 & 1354000 & 12 & 84 & 4 & 9.4 & 0.5 & 5.5 & 10.9 & 25.7 & 7.5 & Heavy clay \\
\hline 19 & 310000 & 1347000 & 14 & 82 & 4 & 7.4 & 0.4 & 4.3 & 10.7 & 25.7 & 11 & Heavy clay \\
\hline 20 & 315000 & 1340000 & 12 & 80 & 8 & 8.1 & 0.4 & 4.7 & 11.7 & 34.2 & 13.9 & Heavy clay \\
\hline 21 & 315000 & 1330000 & 14 & 80 & 6 & 10.8 & 0.5 & 6.3 & 12.5 & 25.7 & 14.9 & Heavy clay \\
\hline 22 & 315000 & 1320000 & 12 & 80 & 8 & 13.4 & 0.7 & 7.8 & 11.1 & 20.6 & 13.9 & Heavy clay \\
\hline 23 & 310000 & 1310000 & 12 & 74 & 14 & 18.2 & 0.9 & 10.6 & 11.7 & 18.9 & 9.6 & Heavy clay \\
\hline 24 & 315000 & 1305000 & 14 & 28 & 58 & 10.8 & 0.5 & 6.3 & 12.5 & 9.5 & 4.5 & Silty clay loam \\
\hline 25 & 316000 & 1300000 & 14 & 26 & 60 & 24.2 & 0.12 & 14 & 11.7 & 18.9 & 4.4 & Silty loam \\
\hline 26 & 320000 & 1290000 & 16 & 60 & 24 & 18.2 & 0.9 & 10.6 & 11.7 & 18 & 8.9 & Clay \\
\hline 27 & 325600 & 1285000 & 66 & 18 & 16 & 14.8 & 0.7 & 8.6 & 12.3 & 13.7 & 4.8 & Sandy loam \\
\hline 28 & 328000 & 1290000 & 14 & 38 & 48 & 23.5 & 1.2 & 13.6 & 11.4 & 12.9 & 3.6 & Silty clay loam \\
\hline 29 & 325000 & 1295000 & 14 & 78 & 8 & 17.5 & 0.9 & 10.2 & 11.3 & 27.4 & 12.5 & Heavy clay \\
\hline 30 & 327500 & 1298600 & 6 & 56 & 38 & 8.7 & 0.4 & 5 & 12.6 & 38.5 & 6.3 & Clay \\
\hline 31 & 330300 & 1300000 & 68 & 16 & 16 & 16.1 & 0.8 & 9.3 & 11.7 & 18 & 6.4 & Sandy loam \\
\hline 32 & 331200 & 1304600 & 22 & 60 & 18 & 22.9 & 1.1 & 13.3 & 12.1 & 17.1 & 5.7 & Clay \\
\hline 33 & 329000 & 1304600 & 16 & 74 & 10 & 14.1 & 0.7 & 8.2 & 11.7 & 6.1 & 14 & Heavy clay \\
\hline 34 & 324000 & 1303000 & 16 & 74 & 10 & 19.5 & 1.0 & 11.3 & 11.3 & 28.2 & 12.4 & Heavy clay \\
\hline 35 & 325000 & 1310000 & 20 & 72 & 8 & 18.8 & 0.9 & 10.9 & 12.1 & 16.3 & 12.8 & Heavy clay \\
\hline 36 & 320000 & 1310000 & 16 & 74 & 10 & 18.2 & 0.9 & 10.6 & 11.7 & 24.8 & 12 & Heavy clay \\
\hline 37 & 326000 & 1320000 & 14 & 80 & 6 & 16.1 & 0.8 & 9.3 & 11.7 & 24 & 14.1 & Heavy clay \\
\hline 38 & 325000 & 1345000 & 12 & 80 & 8 & 18.8 & 0.9 & 10.9 & 12.1 & 6.9 & 12.4 & Heavy clay \\
\hline 39 & 320000 & 1350000 & 18 & 74 & 8 & 6.7 & 0.3 & 3.9 & 13 & 17.1 & 11.5 & Heavy clay \\
\hline 40 & 318000 & 1356000 & 14 & 72 & 14 & 14.1 & 0.7 & 8.2 & 11.7 & 31.6 & 4.1 & Heavy clay \\
\hline 41 & 325000 & 1354000 & 14 & 54 & 32 & 20.2 & 1.0 & 11.7 & 11.7 & 14.6 & 7.9 & Clay \\
\hline 42 & 328000 & 1356500 & 12 & 42 & 46 & 16.1 & 0.8 & 9.3 & 11.7 & 14.6 & 2.9 & Clay \\
\hline 43 & 330000 & 1350000 & 14 & 82 & 4 & 16.1 & 0.8 & 9.3 & 11.7 & 27.4 & 10.5 & Heavy clay \\
\hline 44 & 330000 & 1340000 & 12 & 82 & 6 & 21.5 & 1.1 & 12.5 & 11.3 & 32.5 & 12.9 & Heavy clay \\
\hline 45 & 330000 & 1330000 & 12 & 70 & 18 & 12.1 & 0.6 & 7 & 11.7 & 23.1 & 13.4 & Heavy clay \\
\hline 46 & 330000 & 1315000 & 12 & 82 & 6 & 14.8 & 0.7 & 8.6 & 12.3 & 20.6 & 13.9 & Heavy clay \\
\hline 47 & 335000 & 1310000 & 16 & 72 & 12 & 23.5 & 1.2 & 13.6 & 11.4 & 32.5 & 11.9 & Heavy clay \\
\hline 48 & 334000 & 1316500 & 22 & 24 & 54 & 16.8 & 0.8 & 9.7 & 12.2 & 23.1 & 3.5 & Clay loam \\
\hline 49 & 335000 & 1320000 & 10 & 76 & 14 & 10.8 & 0.5 & 6.3 & 12.5 & 13.7 & 13.1 & Heavy clay \\
\hline 49 & 348000 & 1338000 & 8 & 58 & 34 & 22.2 & 1.1 & 12.9 & 11.7 & 29.1 & 5 & Clay \\
\hline 50 & 335000 & 1345000 & 8 & 84 & 8 & 14.8 & 0.7 & 8.6 & 12.3 & 19.7 & 12.1 & Heavy clay \\
\hline 51 & 300000 & 1340000 & 32 & 66 & 2 & 17.5 & 0.9 & 10.2 & 11.3 & 30.8 & 12.8 & Heavy clay \\
\hline 52 & 336500 & 1359000 & 12 & 72 & 16 & 13.4 & 0.7 & 7.8 & 11.1 & 24 & 3.8 & Heavy clay \\
\hline 53 & 340000 & 1350000 & 12 & 84 & 4 & 14.1 & 0.7 & 8.2 & 11.7 & 18.9 & 7.4 & Heavy clay \\
\hline 54 & 340000 & 1340000 & 12 & 84 & 4 & 10.8 & 0.5 & 6.3 & 12.5 & 25.7 & 9.8 & Heavy clay \\
\hline 55 & 340000 & 1330000 & 12 & 80 & 8 & 12.8 & 0.6 & 7.4 & 12.4 & 3.5 & 9.3 & Heavy clay \\
\hline 56 & 340000 & 1320000 & 12 & 42 & 46 & 16.8 & 0.8 & 9.7 & 12.2 & 26.5 & 7.1 & Clay \\
\hline 57 & 343000 & 1325000 & 8 & 42 & 50 & 21.5 & 1.1 & 12.5 & 11.3 & 18 & 4.4 & Clay \\
\hline 58 & 346000 & 1331000 & 8 & 28 & 64 & 20.2 & 1.0 & 11.7 & 11.7 & 29.9 & 3.4 & Silty clay loam \\
\hline 59 & 348000 & 1338000 & 8 & 58 & 34 & 22.2 & 1.1 & 12.9 & 11.7 & 29.1 & 4.951 & Clay \\
\hline 60 & 344400 & 1344700 & 8 & 66 & 26 & 20.2 & 1.0 & 11.7 & 11.7 & 27.4 & 4.5 & Heavy clay \\
\hline
\end{tabular}




\section{References}

1. Hou, X.; Feng, L.; Duan, H.; Chen, X.; Sun, D.; Shi, K. Fifteen-year monitoring of the turbidity dynamics in large lakes and reservoirs in the middle and lower basin of the yangtze river, China. Remote Sens. Environ. 2017, 190, 107-121. [CrossRef]

2. Mortimore, M. Population growth and land degradation. GeoJournal 1993, 31, 15-21. [CrossRef]

3. Kim, S.M.; Jang, T.I.; Kang, M.S.; Im, S.J.; Park, S.W. Gis-based lake sediment budget estimation taking into consideration land use change in an urbanizing catchment area. Environ. Earth Sci. 2014, 71, $2155-2165$. [CrossRef]

4. Chapman, D.V. Water Quality Assessments: A Guide to the Use of Biota, Sediments, and Water in Environmental Monitoring; World Health Organization: Geneva, Switzerland, 1996.

5. Almada Rojas, G.; Palafox, J.T.P.; Uribe, D.M.; Gaytan, J.M.; Garcia, L.F.C.; Figueroa, J.L.A. Morphological, sediment and soil chemical characteristics of dry tropical shallow reservoirs in the southern mexican heghlands. J. Limnol. 2011, 70, 139. [CrossRef]

6. Morris, G.L.; Fan, J. Reservoir Sedimentation Handbook: Design and Management of Dams, Reservoirs, and Watersheds for Sustainable Use; McGraw Hill Professional: New York, NY, USA, 1998.

7. Danz, N.P.; Niemi, G.J.; Regal, R.R.; Hollenhorst, T.; Johnson, L.B.; Hanowski, J.M.; Axler, R.P.; Ciborowski, J.J.; Hrabik, T.; Brady, V.J. Integrated measures of anthropogenic stress in the us great lakes basin. Environ. Manag. 2007, 39, 631-647. [CrossRef]

8. Håkanson, L.; Jansson, M. Principles of Lake Sedimentology; Springer: Berlin/Heidelberg, Germany, 1983; Volume 316.

9. Balamurugan, P.; Vasudevan, S.; Selvaganapathi, R.; Nishikanth, C. Spatial distribution of grain size characteristics and its role in interpreting the sedimentary depositional environment, Kodaikanal Lake, Tamil Nadu, India. J. Earth Sci. Clim. Chang. 2014, 5, 2.

10. Mclaren, P.; Bowles, D. The effects of sediment transport on grain-size distributions. J. Sediment. Petrol. 1985, $55,457-470$.

11. Shu, G.; Collins, M. The use of grain size trends in marine sediment dynamics: A review. Chin. J. Oceanol. Limnol. 2001, 19, 265-271. [CrossRef]

12. Gebremariam, B. Basin Scale Sedimentary and Water Quality: Responses to External Forcing in Lake Abaya, Southern Ethiopian Rift Valley. 2009. Available online: https://refubium.fu-berlin.de/handle/fub188/6983 (accessed on 19 March 2019).

13. Shah, R.A.; Achyuthan, H.; Puthan-Veettil, R.S.; Derwaish, U.; Rafiq, M. Sediment distribution pattern and environmental implications of physico-chemical characteristics of the Akkulam-Veli Lake, South India. Appl. Water Sci. 2019, 9, 188. [CrossRef]

14. Mwamburi, J. Spatial variations in sedimentary organic matter in surficial lake sediments of nyanza gulf (lake victoria, kenya) after invasion of water hyacinth. Lakes Reserv. Res. Manag. 2016, 21, 94-113. [CrossRef]

15. Vijayaraj, R.; Achyuthan, H. Distribution of sediments and organic matter source: Berijam lake, tamil nadu. J. Geol. Soc. India 2015, 86, 620-626. [CrossRef]

16. Lone, A.M.; Shah, R.A.; Achyuthan, H.; Rafiq, M. Source identification of organic matter using $\mathrm{c} / \mathrm{n}$ ratio in freshwater lakes of Kashmir Valley, Western Himalaya, India. Himal. Geol. 2018, 39, 101-114.

17. Hamidi, S.A.; Hosseiny, H.; Ekhtari, N.; Khazaei, B. Using modis remote sensing data for mapping the spatio-temporal variability of water quality and river turbid plume. J. Coast. Conserv. 2017, 21, 939-950. [CrossRef]

18. Fish, G.R.; Andrew, I.A. Nitrogen and phosphorus in the sediments of lake rotorua. N. Z. J. Mar. Freshw. Res. 1980, 14, 121-128. [CrossRef]

19. Wang, L.; Liang, T. Distribution characteristics of phosphorus in the sediments and overlying water of Poyang lake. PLoS ONE 2015, 10, e0125859. [CrossRef] [PubMed]

20. Crane, J.L. Ambient sediment quality conditions in minnesota lakes, USA: Effects of watershed parameters and aquatic health implications. Sci. Total Environ. 2017, 607-608, 1320-1338. [CrossRef]

21. Cheesman, R.E. Lake Tana \& the Blue Nile: An Abyssinian Quest; Frankcas and Company Ltd.: London, UK, 1936. 
22. Roberts, H.M.; Bryant, C.L.; Huws, D.G.; Lamb, H.F. Generating long chronologies for lacustrine sediments using luminescence dating: A 250,000 year record from lake tana, ethiopia. Quat. Sci. Rev. 2018, 202, 66-77. [CrossRef]

23. Lamb, H.F.; Bates, C.R.; Bryant, C.L.; Davies, S.J.; Huws, D.G.; Marshall, M.H.; Roberts, H.M.; Toland, H. 150,000-year palaeoclimate record from northern ethiopia supports early, multiple dispersals of modern humans from Africa. Sci. Rep. 2018, 8, 1-7. [CrossRef]

24. Abate, M.; Nyssen, J.; Moges, M.M.; Enku, T.; Zimale, F.A.; Tilahun, S.A.; Adgo, E.; Steenhuis, T.S. Long-term landscape changes in the lake tana basin as evidenced by delta development and floodplain aggradation in ethiopia. Land Degrad. Dev. 2017, 28, 1820-1830. [CrossRef]

25. Wondie, A.; Mengistu, S.; Vijverberg, J.; Dejen, E. Seasonal variation in primary production of a large high altitude tropical lake (lake tana, ethiopia): Effects of nutrient availability and water transparency. Aquat. Ecol. 2007, 41, 195-207. [CrossRef]

26. Alemu, M.L.; Geset, M.; Mosa, H.M.; Zemale, F.A.; Moges, M.A.; Giri, S.K.; Tillahun, S.A.; Melesse, A.M.; Ayana, E.K.; Steenhuis, T.S. Spatial and temporal trends of recent dissolved phosphorus concentrations in lake tana and its four main tributaries. Land Degrad. Dev. 2017, 28, 1742-1751. [CrossRef]

27. Vijverberg, J.; Sibbing, F.A.; Dejen, E. Lake Tana: Source of the Blue Nile, in The Nile; Springer: Berlin/Heidelberg, Germany, 2009; pp. 163-192.

28. Dejen, E.; Anteneh, W.; Vijverberg, J. The decline of the lake tana (ethiopia) fisheries: Causes and possible solutions. Land Degrad. Dev. 2017, 28, 1842-1851. [CrossRef]

29. Dersseh, M.G.; Kibret, A.A.; Tilahun, S.A.; Worqlul, A.W.; Moges, M.A.; Dagnew, D.C.; Abebe, W.B.; Melesse, A.M. Potential of water hyacinth infestation on lake tana, ethiopia: A prediction using a gis-based multi-criteria technique. Water 2019, 11, 1921. [CrossRef]

30. Goshu, G.; Byamukama, D.; Manafi, M.; Kirschner, A.K.; Farnleitner, A.H. A pilot study on anthropogenic faecal pollution impact in bahir dar gulf of lake tana, northern ethiopia. Ecohydrol. Hydrobiol. 2010, 10, 271-279. [CrossRef]

31. Goshu, G.; Koelmans, A.; de Klein, J. Water Quality of Lake Tana Basin, Upper Blue Nile, Ethiopia. A Review of Available Data, in Social and Ecological System Dynamics; Springer: Berlin/Heidelberg, Germany, 2017; pp. 127-141.

32. Anteneh, W.; Dereje, T.; Addisalem, A.; Abebaw, Z.; Befta, T. Water Hyacinth Coverage Survey Report on Lake Tana; Bahir Dar University: Bahir Dar, Ethiopia, 2015.

33. Wondie, A. Dynamics of the Major Phytoplankton and Zooplankton Communities and Their Role in the Food Web of Lake Tana, Ethiopia. Ph.D. Thesis, Addis Ababa University, Addis Ababa, Ethiopia, 2006; 162p.

34. Ligdi, E.E.; El Kahloun, M.; Meire, P. Ecohydrological status of lake tana-A shallow highland lake in the blue nile (abbay) basin in ethiopia. Ecohydrol. Hydrobiol. 2010, 10, 109-122. [CrossRef]

35. Wondim, Y.K.; Mosa, H.M. Spatial variation of sediment physicochemical characteristics of lake tana, ethiopia. J. Environ. Earth Sci. 2015, 5, 95-109.

36. Ewnetu, D.A. Determination of Surface Water Quality Status and Identifying Potential Pollution Sources of Lake Tana: Particular Emphasis on the Lake Boundary of Bahirdar City, Amhara Region, North West Ethiopia. J. Environ. Earth Sci. 2014.

37. Kaba, E. Validation of Altimetry Lake Level Data and Its Application in Water Resources Management. Master's Thesis, ITC, Enschede, The Netherlands, 2007.

38. Zimale, F.A.; Moges, M.A.; Alemu, M.L.; Ayana, E.K.; Demissie, S.S.; Tilahun, S.A.; Steenhuis, T.S. Budgeting suspended sediment fluxes in tropical monsoonal watersheds with limited data: The lake tana basin. J. Hydrol. Hydromech. 2018, 66, 65-78. [CrossRef]

39. Lemma, H.; Admasu, T.; Dessie, M.; Fentie, D.; Deckers, J.; Frankl, A.; Poesen, J.; Adgo, E.; Nyssen, J. Revisiting lake sediment budgets: How the calculation of lake lifetime is strongly data and method dependent. Earth Surf. Process. Landf. 2018, 43, 593-607. [CrossRef]

40. Poppe, L.; Frankl, A.; Poesen, J.; Admasu, T.; Dessie, M.; Adgo, E.; Deckers, J.; Nyssen, J. Geomorphology of the lake tana basin, ethiopia. J. Maps 2013, 9, 431-437. [CrossRef]

41. Worku, M. Ecosystem services and tourism potential in lake tana peninsula: Ethiopia review. J. Tour. Hosp. 2017, 6, 2167-0269. [CrossRef]

42. Worku, M. Lake tana as biosphere reserve: Review. J. Tour. Hosp. 2017, 6, 2167. [CrossRef] 
43. Awulachew, S.B.; McCartney, M.; Steenhuis, T.S.; Ahmed, A.A. A Review of Hydrology, Sediment and Water Resource Use in the Blue Nile Basin; IWMI: Addis Ababa, Ethiopia, 2009; Volume 131.

44. Wosenie, M.D.; Verhoest, N.; Pauwels, V.; Negatu, T.A.; Poesen, J.; Adgo, E.; Deckers, J.; Nyssen, J. Analyzing runoff processes through conceptual hydrological modeling in the upper blue nile basin, ethiopia. Hydrol. Earth Syst. Sci. 2014, 18, 5149-5167.

45. Zegeye, A.D.; Langendoen, E.J.; Stoof, C.R.; Tilahun, S.A.; Dagnew, D.C.; Zimale, F.A.; Guzman, C.D.; Yitaferu, B.; Steenhuis, T.S. Morphological dynamics of gully systems in the subhumid ethiopian highlands: The debre mawi watershed. Soil 2016, 2, 443-458. [CrossRef]

46. Taffese, T.; Tilahun, S.A.; Steenhuis, T.S. Phosphorus modeling, in lake tana basin, ethiopia. J. Environ. Hum. 2014, 2, 47-55. [CrossRef]

47. Moges, M.A.; Schmitter, P.; Tilahun, S.A.; Ayana, E.K.; Ketema, A.A.; Nigussie, T.E.; Steenhuis, T.S. Water quality assessment by measuring and using landsat $7 \mathrm{etm}+$ images for the current and previous trend perspective: Lake tana ethiopia. J. Water Resour. Protect. 2017, 9, 1564. [CrossRef]

48. Ekman, S. Neue apparate zur qualitativen und quantitativen erforschung der bodenfauna der seen. Int. Rev. Gesamten Hydrobiol. Hydrogr. 1911, 3, 553-561. [CrossRef]

49. Dewis, J.; Freitas, F. Physical and Chemical Methods of Soil and Water Analysis; FAO Soils Bulletin: Rome, Italy, 1970.

50. Garc a-Gaines, R.A.; Frankenstein, S. Uscs and the Usda Soil Classification System: Development of a Mapping Scheme; Engineer Research And Development Center Hanover Nh Cold Regions Research: Hanover, NH, USA, 2015.

51. Bartlett, G.; Craze, B.; Stone, M.; Crouch, R. Guidelines for Analytical Laboratory Safety; Department of Conservation \& Land Management: Hanover, NH, USA, 1994.

52. Hyne, N.J. The distribution and source of organic matter in reservoir sediments. Environ. Geol. 1978, 2, 279-287. [CrossRef]

53. Johnston, K.; Hoef, J.M.V.; Krivoruchko, K.; Lucas, N. Using Arcgis Geostatistical Analyst; ESRI: Redlands, CA, USA, 2001; Volume 380.

54. Blais, J.M.; Kalff, J. The influence of lake morphometry on sediment focusing. Limnol. Oceanogr. 1995, 40, 582-588. [CrossRef]

55. Abate, M.; Nyssen, J.; Steenhuis, T.S.; Moges, M.M.; Tilahun, S.A.; Enku, T.; Adgo, E. Morphological changes of gumara river channel over 50 years, upper blue nile basin, ethiopia. J. Hydrol. 2015, 525, 152-164. [CrossRef]

56. Dargahi, B.; Setegn, S.G. Combined 3d hydrodynamic and watershed modelling of lake tana, ethiopia. J. Hydrol. 2011, 398, 44-64. [CrossRef]

57. Campbell, L.M.; Hecky, R.E.; Muggide, R.; Dixon, D.G.; Ramlal, P.S. Variation and distribution of total mercury in water, sediment and soil from northern lake victoria, east africa. Biogeochemistry 2003, 65, 195-211. [CrossRef]

58. Ellis, G.S.; Katz, B.J.; Scholz, C.A.; Swart, P.K. Organic Sedimentation in Modern Lacustrine Systems: A Case Study from Lake Malawi, East Africa. Paying Attention to Mudrocks: Priceless; Geological Society of America: New York, NY, USA, 2015; pp. 19-47.

59. Soreghan, M.J.; Cohen, A.S. Textural and compositional variability across littoral segments of lake tanganyika: The effect of asymmetric basin structure on sedimentation in large rift lakes. AAPG Bull. Am. Assoc. Pet. Geol. 1996, 80, 382-409.

60. Li, J.Y.; Brown, E.T.; Crowe, S.A.; Katsev, S. Sediment geochemistry and contributions to carbon and nutrient cycling in a deep meromictic tropical lake: Lake malawi (east africa). J. Great Lakes Res. 2018, 44, 1221-1234. [CrossRef]

61. Olando, G.; Olaka, L.A.; Okinda, P.O.; Abuom, P. Heavy metals in surface sediments of lake naivasha, kenya: Spatial distribution, source identification and ecological risk assessment. SN Appl. Sci. 2020, 2, 279. [CrossRef]

62. Howell, P.P.; Allan, J.A. The Nile: Sharing a Scarce Resource; Howell, P.P., Allan, J.A., Eds.; Cambridge University Press: Cambridge, UK, 1994; p. 426. ISBN 0521450403.

63. Shah, R.A.; Achyuthan, H.; Lone, A.M.; Ramanibai, R. Diatoms, spatial distribution and physicochemical characteristics of the wular lake sediments, kashmir valley, jammu and kashmir. J. Geol. Soc. India 2017, 90, 159-168. [CrossRef] 
64. Wassmann, P. Sedimentation of organic and inorganic particulate material in lindaaspollene, a stratified, land-locked fjord in western norway. Mar. Ecol. Prog. Ser. Oldend. 1983, 13, 237-248. [CrossRef]

65. Meyers, P.A. Preservation of elemental and isotopic source identification of sedimentary organic-matter. Chem. Geol. 1994, 114, 289-302. [CrossRef]

66. Moges, M.A.; Tilahun, S.A.; Ayana, E.K.; Moges, M.M.; Gabye, N.; Giri, S.; Steenhuis, T.S. Non-point source pollution of dissolved phosphorus in the ethiopian highlands: The awramba watershed near lake tana. Clean Soil Air Water 2016, 44, 703-709. [CrossRef]

(C) 2020 by the authors. Licensee MDPI, Basel, Switzerland. This article is an open access article distributed under the terms and conditions of the Creative Commons Attribution (CC BY) license (http://creativecommons.org/licenses/by/4.0/). 